\title{
Effect of Coal Mining on the Abiotic Environment in Pantai Cabe Village, Tapin Selatan District Tapin Regency
}

\author{
Sidharta Adyatma ${ }^{1 *}$ Muhammad Muhaimin ${ }^{1}$ Aswin Nur Saputra ${ }^{1}$ Faisal Arif Setiawan ${ }^{1}$ \\ Akhmad Munaya Rahman ${ }^{1}$ \\ ${ }^{1}$ Geography Education Department, Faculty of Teacher Training and Education, Lambung Mangkurat University, \\ Banjarmasin, Indonesia \\ ${ }^{*}$ Corresponding author. Email: sidharta.adyatma@ulm.ac.id
}

\begin{abstract}
Study That Examines the effect of coal mining on the environment in the village abiotic Chilli Beach District of South Tapin, Tapin. This study aims to determine the effect of coal mining on the abiotic environment based on community perceptions in Pantai Cabe Village, Tapin Selatan District, Tapin District. This study used a qualitative descriptive method by describing community perceptions in Pantai Cabe Village, Tapin Selatan District, Tapin District. The samples were determined using a random technique with a sample size of 96 households. Percentage techniques used to analyze data and categories of public perception are calculated based on the maximum and minimum weights of the variable description of the study. The results showed that of 96 households, 48 families or $50 \%$ had a perception that the presence of coal mining in Pantai Pantai Cabe greatly influenced the abiotic environment in Tapin Selatan District, 40 households or $41.67 \%$ had a perception that the existence of coal mining in Pantai Pantai Cabe enough to affect the abiotic environmental conditions in the South Tapin District and 8 families or $8.33 \%$ have the perception that the existence of coal mining in Pantai Cabe Village does not affect the abiotic environmental conditions in the South Tapin District.
\end{abstract}

Keywords: Influence, Coal Mining, Abiotic Environment

\section{INTRODUCTION}

Human activity in exploiting natural resources will surely cause various impacts, both positive and negative ones. Positive environmental impacts will provide a favorable condition for all who live around the area, while negative environmental impacts are a limiting factor which if neglected will cause damage to the condition of the land around the mining area [1]-[3].

The definition of mining based on the Law of the Republic of Indonesia Number 4 of 2009 concerning Mineral and Coal Mining is a method of mining natural resources by digging the mined land in an area that has been studied previously. Mining has a lot of negative environmental impacts, mining by open-pit mining, which is a method of mining carried out by removing the overburden so that the mined rock is exposed, then the rock is taken [4]. Such mining methods can disrupt the water system around the mining area and the formation of cliffs, thus triggering rock/soil collapse, increased stockpile of material which is easily eroded by surface water flow, causing an increase in river muddy water levels, damage to the shape of river water landscapes and so on [5],[6].

Data from Indonesia Minerals and Coal Statistics in 2005, it is known that coal production in South Kalimantan in 2003 amounted to $46,116,289.80$ tons and in 2004 increased to $54,540,977.16$ tons, the majority of coal production was produced by large companies with foreign capital (Foreign
Investors), such as PT. Arutmin and PT. Adaro Indonesia. This amount of production accounted for $40.35 \%$ of the total national production of $114,278,195.13$ tons in 2003 and $41.21 \%$ of the total national production of $132,352,024.79$ tons in 2004.

Definition of impact according to the Big Indonesian Dictionary is an influence that can bring negative or positive consequences, while the meaning of mining itself is a way of mining natural resources by digging the mined land in an area that has been studied previously. Damage is a condition where something is no longer perfect [7], while the definition of land in the Government Regulation as stated in Government Regulation Number 41 of 1999 concerning Environmental Damage and or Pollution Control Related to Forest and Land Fire is a stretch of terrestrial ecosystem intended for businesses in the forestry, plantation, agriculture, transmigration, mining, tourism and farming fields for the community. The land has the characteristics of summarizing all identifiers of the biosphere, atmosphere, soil, hydrology, geology, reliefs, plant and animal populations, as well as the results of past and present human activities that are stable and recycled. Based on the above understanding it can be concluded that land damage is a state of land which is a biotic and abiotic environment that has lost its carrying capacity to the life and welfare of plants, animals, and humans. 
The environment is an area or region with surrounding circumstances that affect biophysical development and behavior. The environment can be divided into the abiotic environment and biotic environment [8].

Open mining is very easy to cause negative environmental impacts, which can reduce the quality of the environment because it is located not far from residential areas, urban areas, and agriculture. The negative impact of the open pit is the increased erosion (erosion) either in the quarry area or on the mining roads that are built into the mine area, namely the steep slopes of the mine pit, the furrows that extend from the top of the excavation cliff to the bottom excavation. Also, the rapid erosion process that occurs on the slopes that are opened can increase the siltation of the river channel and thus cause a reduction in the capacity of the river channels and excess water volume during the rainy season will overflow out of the river channel and flood the areas around the river channel [9].

Tapin Regency is one of the 13 districts/cities in South Kalimantan. Tapin Regency has an area of $2,174.95 \mathrm{Km}^{2}$ or less than $43 \%$ of the entire area of South Kalimantan Province [10]. South Tapin Subdistrict is one of the 10 subdistricts in the Tapin Regency with a total area of $366 \mathrm{Km}^{2}$ and its mining area is around $68,563 \mathrm{Km}^{2}$. The total population in Tapin Selatan District is around 23,013 people with a total number of family heads of 6,592 families with a population density of $263 / \mathrm{Km}^{2}$. The majority of the population are migrants from Java and Bali who are transmigrants and other residents are indigenous [10]. Pantai Cabe Village is one of the villages in Tapin Selatan District which has an area of around $34 \mathrm{Km}^{2}$. The population in the village of Pantai Cabe is around 1615 people with the number of family heads of 480 families and with a population density of $48 / \mathrm{Km}^{2}$. The main livelihood of the population in the district of South Tapin of them are in agriculture, plantation, and mining.

PT. Sumber Kurnia Buana (PT. SKB) is a private company that in 1999 conducted research and conducted mining in parts of Binuang District and South Tapin District. Coal reserves in the area are $10,920 \mathrm{Ha}$, with a potential of $33,663,494$ tons, which are divided into three groups based on their depth, which is between $0-50 \mathrm{~m}$ totaling $8,318,690$ tons, between $50-100 \mathrm{~m}$ totaling $12,957,953$ tons and between $100-150 \mathrm{~m}$ of $12,392,851$ tons. Annual production is 650,000 tons [11]. PT SKB is now utilizing dynamite explosive power to obtain coal. The use of explosives was carried out to support the planned increase in production from 8,000 metric tons per year to 1.5 million metric tons per year [10].

The mining company has prepared a good mining plan by the requirements set to obtain a permit from the government. But until now there has not been an excavation hole that has been covered again, especially for mining areas in Pantai Cabe Village, Tapin Selatan District, Tapin Regency. In every hill that is being and has been mined, it appears that open holes of various sizes are the impact of the mining, namely the destruction of the landscape which greatly reduces the environmental aesthetics, especially the abiotic environment. Another impact that has arisen is the increasing process of erosion (erosion) on the land. The rapid erosion process that occurs is increasing the sedimentation process in river basins, resulting in shallowing river flow. This shallowing causes a decrease in the capacity of river basins, so that excess volume of water during the rainy season will overflow out of the river channel and flood the areas around the river channel, while in the dry season the dust is very concentrated floating around the mine road [12].

\section{THEORETICAL FRAMEWORK \\ 2.1 Community Perception}

Perception is a person's view or response to a problem according to his opinion or ideas. Perception is a psychiatric factor whose contribution to a person's behavior is quite large. Perception is the process of selecting a stimulus from its environment and then organizing and interpreting the sense impressions or catches to have meaning in the context of its environment [13]. Society is any group of people who have lived and worked together long enough so that they organize themselves as a social entity. Based on some of the above notions of perception, it can be concluded that community perception is the response given by society to everything that is captured by the five senses after it has been previously processed through the organization and interpretation of impressions and is formed from several factors that interact with each other and are bound to each other social relations.

\subsection{Abiotic Environment}

The environment is "around", especially circumstances that affect human life. The term environment is usually used to refer to nature surrounding human life consisting of the biosphere, hydrosphere, and atmosphere. Explain that the environment is an area or region with surrounding circumstances that affect the development and behavior of biophysics. The environment is an ecosystem consisting of various regions, each as a subsystem that includes sociocultural, economic, and physical aspects with different features of the different subsystems with different environmental carrying capacity [8]. While the understanding of the environment according to Law No. 32 of 2009 is a unity of space with all objects, power, conditions, and living things, including humans and their behavior, which affects the survival and welfare of humans and other living things. While the scope of Indonesia's environment includes space, where the Unitary State of the Republic of Indonesia is archipelago-minded in exercising its sovereignty, sovereign rights, and jurisdiction.

\subsection{Coal Mining}

Mining is a way of mining natural resources by digging the mined land in an area that has been studied previously [14], currently in [15] concerning Prevention and Management of Environmental Damage and Pollution in General Mining Business Activities, it was explained that mining is an activity carried out either manually or mechanically to obtain quarry materials. Coal is a hard sedimentary rock and is black in color, formed through the process of freezing or coagulation of plant material that grew more than 200 
million years ago. Coal has a higher carbon content and less water.

\section{METHOD}

This study uses a qualitative descriptive approach with a series of activities to reveal an unknown problem by collecting data by making a systematic, factual and accurate descriptive, picture or painting of facts, properties and relationships between phenomena investigated through information regarding the current situation using systematic, directed and accountable work methods.

\subsection{Study Area Description}

This research was conducted in Tapin Selatan District, Tapin District. This sub-district was chosen as a research area because of the method of coal mining used as open-pit mining, which was very easy to hurt the abiotic environment in the area around the mining location, especially for Pantai Cabe Village, Tapin Selatan District.

\subsection{Sample}

If the subjects of the population are less than 100 , it is better to take all of them so that the research is population research, then if the number of subjects from the population is more than 100 then the sample can be taken between $10 \%$ $-15 \%, 20 \%-25 \%$ or more. The size of the sample in this study only took $20 \%$ of the total population. The number of populations and samples are presented in Table 1 .

Table 1 Number of Populations and Research Samples Research

\begin{tabular}{|c|c|c|c|}
\hline Area & $\begin{array}{c}\text { Number of population } \\
(\text { KK) }\end{array}$ & $\begin{array}{c}\text { Percentage } \\
(\%)\end{array}$ & Number of Samples (KK) \\
\hline Pantai Cabe Village, Tapin Selatan District & 480 & 20 & 96 \\
\hline
\end{tabular}

\subsection{Research Variable}

Variables are factors that are tested in research. This research activity is focused on efforts to understand and assess the relationship between these variables. The research variables are presented in Table 2 .

Table 2 Exposition of Research Variables

\begin{tabular}{|c|c|c|c|}
\hline $\begin{array}{c}\text { IV } \\
\text { (independent variable) }\end{array}$ & $\begin{array}{c}\text { DV } \\
\text { (dependent variable) }\end{array}$ & Data collection techniques Data & analysis \\
\hline Coal Mining & $\begin{array}{c}\text { Abiotic Environment (soil, } \\
\text { water, air) }\end{array}$ & $\begin{array}{c}\text { Direct observation, questionnaire, } \\
\text { interview, documentation }\end{array}$ & Statistical analysis \\
\hline
\end{tabular}

Based on Table 2 the variables used in this study are 2 variables: the dependent variable is the abiotic environment and the independent variable is coal mining.

\subsection{Data Analysis Technique}

Primary data obtained in this study were analyzed using random or random techniques using calculations percentage. Primary data in the form of the results of respondents 'answers to the questionnaire/interview are presented with a single tabulation and calculated as the percentage and the results of the respondents' answers then given a conclusion. Steps for completion:

1. Counting the number of alternative answers chosen by respondents as many as 96 people.

2. Count the number of answers chosen by respondents by the answer categories.

3. The entire questionnaire returned by the respondent is calculated, the calculation result data that has been collected pursuant questionnaire alternative answers there and then tabulate using the technique the percentage with the following formula:

$P \frac{f}{N} \times 100 \%$

Description:

$\mathrm{P}=$ Percentage of respondents' answers
$\mathrm{f}=$ Frequency of answers
$\mathrm{N}=$ Number of respondents who gave answers

\section{RESULTS AND DISCUSSION}

Effect of coal mining on the abiotic environment in Pantai Cabe Desa Tapin Selatan District, Tapin District in this study the effect variable is coal mining which includes community perceptions in Pantai Pantai Chili and its affected variables are the abiotic environment including land, water, and the air around coal mining in Pantai Cabe Village, Tapin Selatan District, Tapin Regency.

\subsection{Age}

Respondents in the study aged between $<30$ years to $>50$ years, because the age range already has responsibilities. Respondents in Pantai Cabe at the age of $\leq 30$ years the percentage of respondents was $(17.71 \%)$, ages $30-<40$ years $(34.37 \%), 40-<50$ years the percentage of respondents was $(26.04 \%)$, and $\geq 50$ years the percentage of respondents was (21.88\%). Based on the description that the percentage highest of respondents age is $30-<40$ years old and the percentage lowest age $\leq 30$ years.

\subsection{Type of work}

The type of work is related to the respondents' opinion on the existence of coal mining in Pantai Cabe Village, Tapin Selatan District. Most respondents work as farmers by $41.66 \%$, work as laborers in rubber plantations and coal mining by $26.04 \%$, work as traders for $19.80 \%$, and work in the service sector and others for $12.50 \%$. The large number 
of respondents who work as farmers is because the majority of Pantai Cabe Village residents work in the agricultural sector.

\subsection{Length of stay}

Length of stay of the respondent relates to the opinion of the respondent on the abiotic environment of Pantai Cabe Village, Tapin Selatan District before the existence of coal mining activities or after the mining activities. Most respondents who lived in Pantai Cabe Village for $\geq 10$ years amounted to $42.70 \%$, respondents with a length of stay $\leq 5$ years amounted to $23.95 \%$, and respondents with a length of stay $5-<8$ years and respondents with a length of stay 8 $<10$ years at $16.66 \%$.

\subsection{Respondents' Perception of Residential Location}

Locations in the study greatly affect respondents in giving opinions/perceptions about the state of the environment in the area of residence. Respondents who respond to the influence of coal mining depend on the location of their residence. The closer the respondent's residence location to the mining location, the respondent's perception of the influence of coal mining on the abiotic environment will be negative, and vice versa. Respondents who reside $\mathrm{km} 3 \mathrm{~km}$ from the mining location by $49 \%$, resident $1-<2 \mathrm{~km}$ from the mining location by $27.1 \%$, respondents reside $2-<3 \mathrm{~km}$ from the mining location by $14.6 \%$, and respondents who live residing $\leq 1 \mathrm{~km}$ from the mining location at $9.3 \%$.

The location of the respondent's residence in this study by road/coal transportation traffic also greatly influenced the respondent in giving his opinion/perception about the state of the environment in the area of his residence. The closer the respondent's residence location to the mining location, the respondent's perception of the influence of coal transportation road/traffic on the respondent's residence will be negative. Respondents who live $\geq 30 \mathrm{~m}$ from the road / coal transportation traffic by $35.40 \%$, respondents who reside 10- $<20 \mathrm{~m}$ from the road / coal transportation traffic by $30.20 \%$, respondents reside $\leq 1 \mathrm{~m}$ from the road / coal transportation traffic by $25.00 \%$ and respondents residing $20-<30 \mathrm{~m}$ from the road/traffic coal transportation by $9.40 \%$.

\subsection{Respondents' Perceptions of the Abiotic Environment Before Coal Mining}

\subsubsection{Soil}

Respondents stated that the condition of the land before the existence of coal mining was fertile at $78.13 \%$ and respondents who stated that the condition of the land before the existence of coal mining was infertile at $21.87 \%$. The condition of soil fertility around the respondent's neighborhood, either near or far from the mining location, is very varied. Respondents who stated that the condition of the land before the occurrence of coal mining had experienced a landslide by $27.08 \%$ of respondents and who stated that before the mining of coal had never experienced a landslide of $72.92 \%$ of respondents. Respondents stated that erosion had never occurred before the existence of coal mining by $77.08 \%$ and stated that erosion had occurred before mining at $22.92 \%$.

\subsection{2 $\underline{\text { Water }}$ \\ 4.5.2.1 Surface Water}

The state of water before mining greatly affects respondents in giving their perceptions of the abiotic environment before coal mining in Tapin Selatan District, either in surface water or in groundwater in Pantai Cabe Village, Tapin Selatan District. Respondents who stated that water conditions before coal mining were very clear were $17.70 \%$, respondents who stated water conditions as clear as $26.04 \%$, respondents who stated water conditions as turbid were $36.46 \%$, and respondents which state the condition of the water in a very murky state of $19.80 \%$. Respondents' perceptions which state that water conditions before coal mining had experienced flooding amounted to $30.21 \%$ of respondents and who stated that before coal mining had never experienced flooding amounted to $69.79 \%$ of respondents. This is because of the area of residence of respondents who had experienced flooding $<2$ times a year amounted to $80.20 \%$ and the area of residence of respondents had flooded as much as $2-<3$ times a year amounted to $19.80 \%$.

\subsubsection{Groundwater}

The condition of groundwater before mining greatly influenced respondents in giving their perceptions of the abiotic environment before coal mining in Tapin Selatan District, because the water needs used by respondents in their daily lives were very dependent on the condition of groundwater either in the form of dug well water or water pipe wells. Respondents stated that there were $62.5 \%$ of wells around their homes. The number of respondents stated that this is because they use/use of the well water is usually one dug well can be used for several heads of households. Respondents who did not have a well in the vicinity of their residence amounted to $37.5 \%$ because respondents had used clean water facilities and some used pool water that was formerly excavated coal. Respondents' perceptions of $20.83 \%$ stated that the condition of well water before there was coal mining was clear and the respondent stated that the condition of well water was turbid before mining was $79.17 \%$. Medium, respondents' perceptions which state that the depth of well water before the existence of coal mining had a water depth as high as $1-<4$ meters as much as $32.29 \%$ of respondents and water depth as high as $4-<8$ meters as much as $60.42 \%$ of respondents and water depth as high as $\geq 8$ meters as much as $7.29 \%$, but other factors that affect the depth of the water well are not only the length of coal mining activities but also influenced by seasonal factors.

\subsubsection{Air}

The air condition before mining greatly influenced respondents in giving their perceptions of the abiotic environment before coal mining in Tapin Selatan District, concerning the air condition, noise, and air temperature 
around the respondent's residence due to mining activities. Respondents' perceptions stating about the condition of the air around their residence or the mining location before the presence of coal mining in dusty conditions were $19.79 \%$ of respondents and in dusty conditions were $80.21 \%$ of respondents. Respondents stated that the area experienced a situation where the air around their residence was dusty because the area where they lived was indeed lacking water or in a dry condition especially now that this area was experiencing a dry season.

\subsection{Respondents' Perceptions of the Abiotic Environment After Coal Mining}

\subsubsection{Soil}

Respondents stated that the condition of the land after the coal mining had experienced landslides $66.67 \%$ of respondents and stated that after the mining of coal had never experienced a landslide as much as $33.33 \%$ of respondents. This is due to the activities carried out during coal mining resulting in very strong vibrations coming from heavy equipment or from coal vehicles that pass on the roads. This situation causes landslides on the side of the road to experience landslides.

\subsection{2 $\underline{\text { Water }}$}

\subsubsection{Surface Water}

The state of the water after mining greatly influences the respondent's perception of the abiotic environment in Tapin Selatan District, either in surface water or in groundwater in Pantai Cabe Village, Tapin Selatan District. Respondents' perceptions of the condition of water after the existence of coal mining stated in a murky condition of $30.20 \%$ and respondents who stated that the condition of the water in a very murky condition amounted to $69.80 \%$. As a result of these conditions, the state of surface water, especially river water, is now almost unusable, because water conditions have turned black after coal mining. River water which has been the supply of water distributed by the PDAM can no longer be distributed, this is because it can not make the water that was turbid to be clear again because it has been polluted by coal mining. Respondents' perceptions that the surface water condition after coal mining had flooded $\geq 2$ times in one year amounted to $56.25 \%$ and the area of residence of the respondent had experienced flooding $<2-3$ times in one year amounted to $43.75 \%$.

\subsubsection{Groundwater}

The condition of groundwater after mining greatly influences the respondent in giving his perception of the abiotic environment in Tapin Selatan District, because the water needs used by the respondent in his daily life are very dependent on the condition of groundwater in the form of dug well water or piped well water. The condition of groundwater before mining is known that $16.67 \%$ of respondents stated the condition of well water before there was coal mining in a murky condition and the respondents stated the condition of well water in a very murky condition after mining was $83.33 \%$. Respondents' perception that the depth of well water after the existence of coal mining had a water depth as high as $1-<4$ meters as much as $41.66 \%$ and water depth as high as $4-<8$ meters as much as $51.04 \%$ of respondents and water depth as high as $\geq 8$ meters as much as $730 \%$.

\subsubsection{Air}

Respondents' perceptions stating the condition of the air around their residence or the mining location after the presence of coal mining in a dusty state were $100 \%$ of the respondents. Respondents stated this because the area where they lived was dusty and around $80.72 \%$ of respondents thought that the air condition around their residence was a lot of dust flying and mixed with smoke from heavy equipment used in coal mining.

\section{CONCLUSION}

Research on community perceptions around coal mining locations that have been carried out on the abiotic environment in Pantai Cabe Village, Tapin Selatan District, Tapin District, obtained several conclusions including changes in the quality of the abiotic environment in terms of soil fertility, landslides, river water, well water, and air. Coal mining should use mining methods that do not damage the biotic or abiotic environment so that it does not degrade the quality of the environment around the mine. After mining the reforestation is carried out in the former mining area to prevent erosion or landslides, watering the coal transportation traffic when it is dry so that flying dust decreases.

\section{ACKNOWLEDGMENT}

Thank you to the Faculty of Teacher Training and Education for supporting me to join the international conference. Thank you to my colleagues in the Department of Geography Education for being a good colleague.

\section{REFERENCES}

[1] D. Apriyanto and R. Harini, "Dampak Kegiatan Pertambangan Batubara Terhadap Kondisi Sosialekonomi Masyarakat Di Kelurahan Loa Ipuh Darat, Tenggarong, Kutai Kartanegara," Jurnal Bumi Indonesia, vol. 1, no. 3, Art. no. 3, Oct. 2013, Accessed: Jul. 07, 2020. [Online]. Available:

http://lib.geo.ugm.ac.id/ojs/index.php/jbi/article/ view/96

[2] T. A. Fachlevi, E. I. K. Putri, and S. M. H. Simanjuntak, "Dampak dan Evaluasi Kebijakan Pertambangan Batubara Di Kecamatan Mereubo," Risalah Kebijakan Pertanian dan Lingkungan <br>Rumusan Kajian Strategis Bidang Pertanian dan Lingkungan $</$ br $>$, vol. 2, no. 2, Art. no. 2, 2015, doi: 10.29244/jkebijakan.v2i2.10989. 
[3] S. Risal, D. B. Paranoan, and S. Djaja, “Analisis Dampak Kebijakan Pertambangan Terhadap Kehidupan Sosial Ekonomi Masyarakat Di Kelurahan Makroman," Jurnal Administrative Reform (JAR), vol. 1, no. 3, Art. no. 3, Jul. 2017, doi: $10.30872 /$ jar.vli3.482.

[4] Subowo, "Penambangan Sistem Terbuka Ramah Lingkungan dan Upaya Reklamasi Pasca Tambang untuk Memperbaiki Kualitas Sumberdaya Lahan dan Hayati Tanah," 2011, Accessed: Jul. 07, 2020. [Online]. Available: https://media.neliti.com/media/publications/1327 06-ID-none.pdf.

[5] A. H. Barkatullah, "Menakar Keseimbangan Dampak Positif dan Negatif Terhadap Kebijakan Pertambangan Batubara," bhl, vol. 3, no. 1, pp. 34-48, Oct. 2018, doi: 10.24970/jbhl.v3n1.3.

[6] S. D. Devy, H. Hendrayana, D. P. E. Putra, and E. Sugiharto, "Pemodelan Penyebaran Batuan Potensial Pembentuk Asam Pada Kawasan Penambangan Batubara Tambang Terbuka Di Muara Lawa, Kabupaten Kutai Barat, Kalimantan Timur," Jurnal Manusia dan Lingkungan, vol. 23, no. 1, Art. no. 1, Feb. 2016, doi: 10.22146/jml.18770.

[7] Y. Yudhistira, W. K. Hidayat, and A. Hadiyarto, "Kajian Dampak Kerusakan Lingkungan Akibat Kegiatan Penambangan Pasir Di Desa Keningar Daerah Kawasan Gunung Merapi," J. Ilmu Lingk., vol. 9, no. 2, p. 76, Oct. 2012, doi: 10.14710/ji1.9.2.76-84.

[8] N. H. T. Siahaan, Hukum lingkungan dan ekologi pembangunan, Ed. 2. Ciracas, Jakarta: Erlangga, 2004.

[9] S. Sulasmi, D. P. Ningsih, and F. Ugm, "Pertambangan di Tanah Bumbu: dampak hidrologis dan solusi," p. 1, 2017.

[10] BPS Kabupaten Tapin, Kabupaten Tapin Dalam Angka 2019. 2019.

[11] Ciptakarya, "Penyusunan RPIJM Kabupaten Tapin 2016-2020." 2016.

[12] F. Novico, A. Ali, E. Saputro, A. Sinaga, and A. Egon, "Morfodinamika Jangka Pendek Pendangkalan di Alur Pelayaran Barito, Kalimantan Selatan," JGK, vol. 15, no. 2, Feb. 2018, doi: 10.32693/jgk.15.2.2017.402.

[13] V. Rivai and D. Mulyadi, Kepemimpinan dan Perilaku Organisasi, 4th ed. 2008.

[14] C. Nugraha, "Pengelolaan Lingkungan Pertambangan,” Mar. 2019.

[15] Menteri Energi dan Sumber Daya Mineral Republik Indonesia, "Peraturan Menteri ESDM Nomor 26 Tahun 2018.” 2018, Accessed: Jul. 09, 2020. [Online]. Available: https://jdih.esdm.go.id/peraturan/Peraturan $\% 20$ Menteri\%20ESDM\%20Nomor\%2026\%20Tahun $\% 202018$.pdf. 